\title{
Ethnozoology of bats (Mammalia, Chiroptera) in Feira de Santana Municipality, Bahia State, Northeastern Brazil
}

\author{
Maria da Conceição Borges Gomes ${ }^{1}$, Eraldo Medeiros Costa Neto ${ }^{1 * *}$ \\ and Martin Roberto del Valle Alvarez ${ }^{2}$
}

1Universidade Estadual de Feira de Santana. Departamento de Ciências Biológicas. Av. Transnordestina, S/N ${ }^{\circ}$. Bairro Novo Horizonte. Feira de Santana-BA. Brazil (CEP 44036-900).*Email: eraldont@hotmail.com.

${ }^{2}$ Universidade Estadual de Santa Cruz. Departamento de Ciências Biológicas. Campus Soane Nazaré de Andrade. Rodovia Jorge Amado, km 16. Bairro Salobrinho. IlhéusBA. Brazil (CEP 45662-900).

\begin{abstract}
The ethnozoology studies several manifestations of humans on fauna, whether inspired by affection, rejection, contempt or reverence, which are generally based on local beliefs and symbols. Bats stand out amongst those animals that make up the mythopoetic imaginary since ancient times. This paper records how bats are perceived by rural and urban inhabitants of the Municipality of Feira de Santana, Bahia State, Brazil. Data were collected using semi-structured interviews. Two hundred participants were randomly chosen, 100 residents living in rural areas and 100 living in different districts of the municipality. Data were analyzed qualitatively, considering the set of responses provided by all interviewees. The results showed that the lack of information is the main cause of adverse reactions that people have by bats. Most of these reactions are due to lack of knowledge on bats behavior, especially when it comes to their feeding habits, since the majority of the respondents believed that the consumption of blood is the prevalent diet. After each new interview, information about feeding habits, behavior and general medical care to be taken when having contact with bats, were offered to the participants. This study suggests that education is one of the suitable tools to minimize prejudice against bats.
\end{abstract}

Keywords: Folk knowledge; Ethnozoology; Perception; Vampire bat.
Received

May 11, 2017

Accepted

June 27, 2017

Released

June 30, 2017

Open Acess

Full Text Article

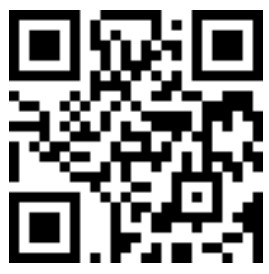

ORCIID

(1) 0000-0002-2980-4796

Maria da Conceição

Borges Gomes

(D) 0000-0003-0278-1974

Eraldo Medeiros Costa

Neto

(ㄷ) 0000-0001-6908-8547

Martin Roberto del

Valle Alvarez

\section{Introduction}

The ethnozoology studies several manifestations of humans on fauna, whether inspired by affection, rejection, contempt or reverence, based on local beliefs and symbols (Mendes et al., 2005).
Bats stand out amongst the animals that make up the mythopoetic imaginary, and they are usually considered undesirable creatures in any environment where they live. Since bats have striking features, such as nocturnal habits, sleeping upside down and have vampire representatives, fanciful 
superstitions abound around them, and people often associate them with darkness, death and evil spirits (Allen, 1967; Alves, 1999; Knight, 2008; Prokop and Tunnicliffe, 2008).

Several studies demonstrate the importance of assessing the perception of people about certain species of animals that are seen as undesirable, such as bats, spiders and snakes, and how this perception influences on the conservation of endangered species (Prokop and Tunnicliffe, 2008; Knight, 2008). In these studies, both the appearance as the myths surrounding bats influence negatively on their protection. Therefore, the works which may reveal and demonstrate the ecological importance of bats are extremely important to raise awareness in conserving these animals.

Even though this group represents nearly a quarter of all mammal species in Brazil (178 species, according to Nogueira et al., 2014), just a few studies with an ethnozoological approach were published on bats. Surveys are specific to certain school groups or other segments of the society. Bruno and Kraemer (2010) recorded the perceptions of students of 6th grade of a public school in Belo Horizonte, while Andrigueto and Cunha (2004) investigated the role of education in the deconstruction of myths and beliefs concerning bats. The most comprehensive study was an unpublished investigation done by Drummond (2004), who surveyed the inhabitants of Vitória da Conquista, located in the Southwestern Region of the State of Bahia.

This paper, an ethnozoological study, was conducted with a group of residents in the city of Feira de Santana, State of Bahia, northeastern Brazil, aiming to document the knowledge and perception on bats considering morphological and behavioral aspects, and concepts related to local beliefs.

\section{Materials and methods}

The Municipality of Feira de Santana is located $108 \mathrm{~km}$ from Salvador, the capital of Bahia State. With about 606,139 inhabitants, it's the second largest population in Bahia State (IBGE, 2013). It is comprised of 47 neighborhoods and eight districts: Bonfim de Feira and Governor João Durval Carneiro, to the west; Humildes and Jaíba to the east; and Jaguara, Maria Quitéria, Matinha and Tiquaruçu to the north (Figure 1).

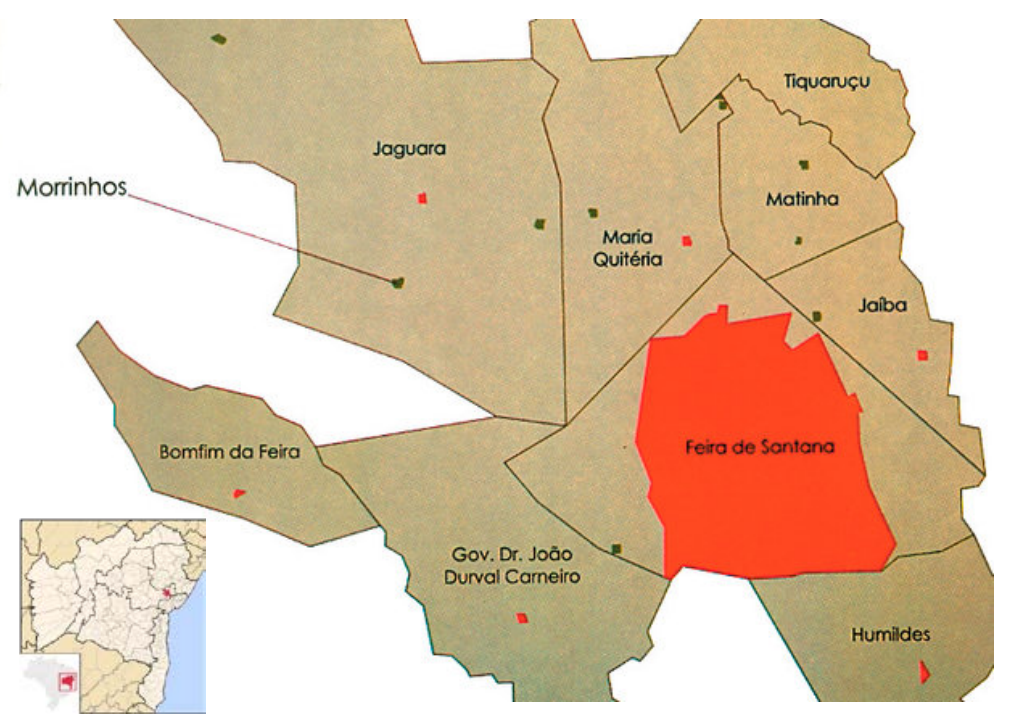

Figure 1. The localization of Feira de Santana Municipality and the districts that comprise it. 
The ethnozoological data were obtained by semi-structured interviews performed with 200 persons, divided into two groups: 100 living in rural areas of the districts of Maria Quitéria and Humildes, and 100 living in urban area. Urban residents were interviewed from August 2011 to August 2014, while those habitants of Maria Quitéria and Humildes were interviewed in December 2014. The project was approved by the Research Committee of Ethic, of the State University of Feira de Santana (CAAE Number 0056.059.000-11).

The data were analyzed qualitatively and quantitatively considering the set of responses provided by all participants. For evidentiary purposes, the interviews will be stored at the
Ethnobiology Laboratory of the State University of Feira de Santana for a period of five years since the publications of this paper.

\section{Results}

In the urban area, 43 men and 57 women were interviewed. Their average age was 35 years. All respondents were adults, aged 18 to 78 years. Of the 47 neighborhoods of the city, $91 \%$ were sampled. In the rural area, 20 men and 30 women were interviewed in Maria Quitéria, and 30 men and 20 women were contacted in Humildes. Their average age was 43 years. Interviewees presented different levels of education (Table 1).

Table 1. Characteristics of the sample surveyed.

\begin{tabular}{|c|c|c|}
\hline & Urban area & Rural area \\
\hline Samples & 100 & 100 \\
\hline Districts & $42(91 \%)$ & $2(100 \%)$ \\
\hline Period & August 2011 - August 2014 & December 2014 \\
\hline Male / Female & $43 / 57$ & $50 / 50$ \\
\hline Average age & 35 & 43 \\
\hline \multicolumn{3}{|l|}{ Educational levels: } \\
\hline - Functional illiterate & 4 & 1 \\
\hline - Incomplete primary education & 26 & 6 \\
\hline - Complete elementary education & 13 & 1 \\
\hline - Incomplete secondary education & 15 & 10 \\
\hline - Completed high school & 36 & 34 \\
\hline - Incomplete higher education & 4 & 30 \\
\hline - University graduates & 2 & 18 \\
\hline
\end{tabular}

With regard to the first question of the questionnaire, related to ethnozoological classification, several persons categorized bats in the animal kingdom, besides the class Mammalia. Of the 100 respondents in the urban area, 42 did not include bats in Class Mammalia, 57 of them indicated that bats were mammals, and only one respondent did not answer it. Of the 42 respondents who do not recognize the bats as mammals, $14 \%$ considered them as a type of mouse, $17 \%$ a type of insect, $14 \%$ a kind of bird, $7 \%$ believe they are vampires, and $2 \%$ said that bats are reptiles. In the rural area, $86 \%$ of the respondents have had some kind of classification. Of these, only $17 \%$ named the bats as mammals. The percentage of registered categories is: $8 \%$ as bird; $21 \%$ as insects; $12 \%$ as mice; $1 \%$ as vampires (Figure 2 ). 


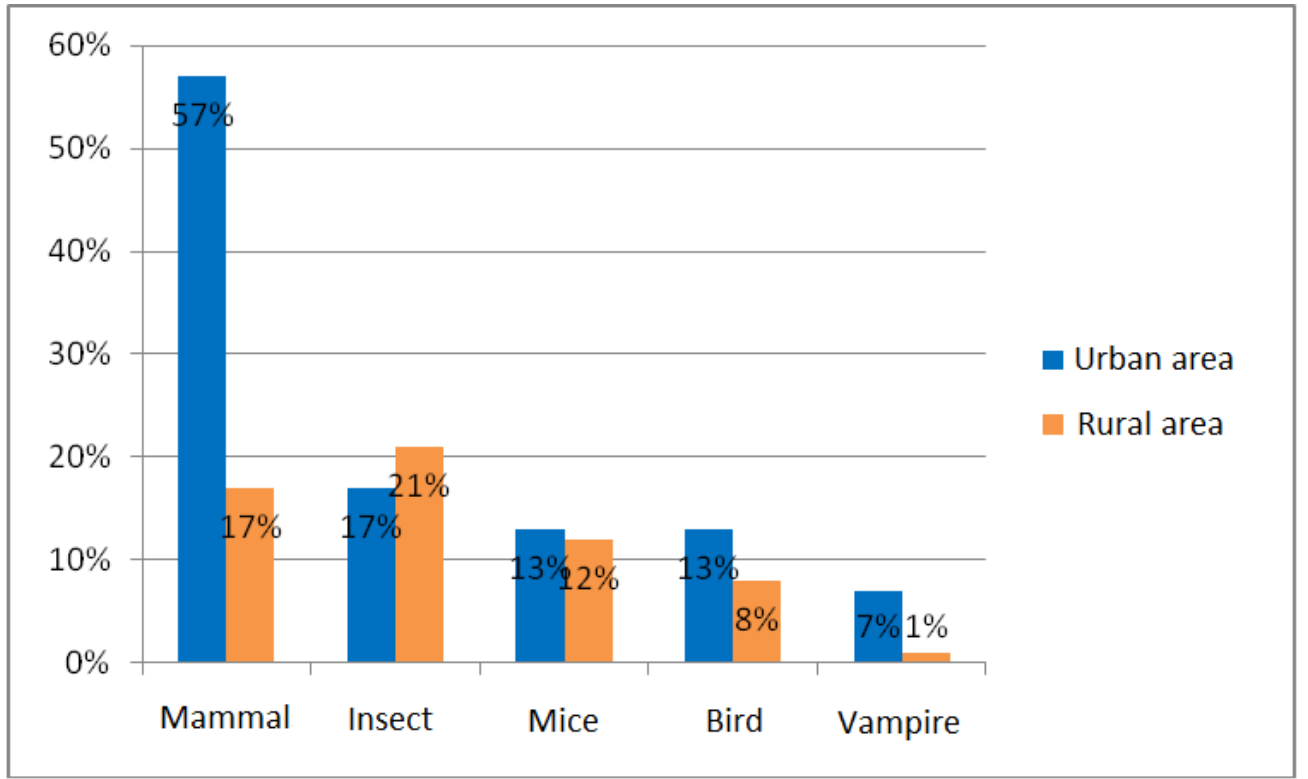

Figure 2. Ethnozoological classification of bats according to the interviewers in the Municipality of Feira de Santana (Bahia State, Brazil), comparing between urban and rural areas.

We highlight the following answers related to folk ethnozoological classification:

"It is an animal that flies, transmitting disease through biting, like a bird" (man, 64).

"A boring, smelly creature; mouse family” (woman, 55).

"It is an insect that destroys the home" (woman, 44).

"It is a mammalian bird" (man, 34).

In the urban area, among the respondents who did not classify the bats, $24 \%$ associated them to some pejorative adjectives (disgusting, awful, ugly etc.), and another $24 \%$ associated them with the habit of flying (flying animal; beast that has two wings etc.). In rural areas, $22 \%$ of the participants mentioned categorizations based on unpleasant adjectives (dangerous animal, contaminated, harmful, poisonous, pest, transmitter of disease), and 15\% reported their perception on bats: mammalian bird, parasite that sucks blood, nocturnal animal, and flying animal. As for the associations to pejorative adjectives, the following respondents' answers can be cited:
"It is a transmitter of animal disease. It is seen only at night and lives upside down" (woman, 49).

"An aggressive animal to human being” (man, 65 years).

“A contagious animal” (man, 33).

"An ugly and disgusting animal” (woman, 18 years).

In urban area, when we asked what the reaction if find a bat, $13 \%$ of respondents reported that kill or try to kill it, while $37 \%$ are in terror and panic reactions. About 49\% reported doing nothing, just to observe, or try to get it away from home without killing it; only $1 \%$ reported that authorities are called to get rid of them. In rural areas, $28 \%$ of respondents reported that they killed or try to kill it, while $36 \%$ have dread and fear responses. About 36\% reported doing nothing, just observe, or try to get it away from home without killing it.

The frugivorous habits were cited 73 times in urban areas, followed by carnivorous (44) and insectivorous (37). There were other reports on feeding habits, like nectar (4), pollen (3), leaves (1), all corroborating with the literature. However, there was a report that bats feed roots, fungi 
and sap, which is not consistent with the literature to date. However, 13\% of respondents did not know the feeding habits of bats. In the rural area, frugivory was cited 35 times, followed by biting (33) and insectivory (28). The carnivorous habit (eating small animals) was cited eight times. There were other reports, such as leaves (1), seeds, (2) herbs (1), garbage (1), and that bats eat everything (1). Among the respondents, 36\% did not know the diets of bats. Here are some examples of the responses of respondents on the feeding habits of bats:

"I heard it likes to suck people's blood" (woman, 76).

"I've seen it sucking blood" (man, 18 years).

"It eats fruit, eats everything” (woman, $19)$.

"According to people's saying, it eats red berries but I believe it does not" (man, 40 years).

Considering bat species diversity, $52 \%$ of respondents from urban area said they do not know how to distinguish among species, however, they believe there are several types of bats. To $43 \%$ there is only one type of bat, and $5 \%$ cited three types. In rural areas, $62 \%$ of respondents answered that there are several types of bats, but they do not know how many and how to distinguish one from another. For 36\% of respondents bats are all equal, that is, there is only one type of bat. For $2 \%$ there are three or four kinds of bats.

With regard to legends and myths about bats, $43 \%$ of respondents in urban areas reported not knowing or remembering any folk narrative. The legend of the vampire has been cited 26 times, seven of them referring to Dracula's legend; Batman's legend has been cited seven times. Seven other reports appeared: the urine of a bat is blue; bats are blind; they make braid in the mane of horses; a bat sucked the blood of Jesus Christ; if the hair of a bat enters someone's eye this will cause blindness; a bat is an old mouse with wings; they suck the blood of the animal until it dies.
In rural areas, $54 \%$ of respondents reported not knowing or not remembering any stories, but $6 \%$ cited the vampire legend, without referring to Count Dracula, $2 \%$ said they know the Batman legend from drawings and films, and only one interviewed associated the image of the bat with Halloween. Six myths appeared in the reports: bats are blind; they suck blood; a bitten person dies; an old rat turns into a bat; bats are poisonous; bats only see at night.

When asking about the use of bats to cure diseases, either in the traditional or conventional medicine, $54 \%$ and $68 \%$ of respondents in urban and rural areas, respectively, did not believe that bats could provide a product for the cure of diseases. Only $12 \%$ in urban areas and $14 \%$ in rural areas said that bats can contribute to cure/ treatment of diseases, e.g., strokes (stroke) and circulatory problems, due to the presence of anticoagulant substances in the saliva, or to the treatment of cancer. The rest of the respondents could not answer or did not have knowledge about it.

Regarding the use of bats as a human food, only $20 \%$ of respondents in urban areas said they knew about the use of bats as food, $67 \%$ believe that bats do not serve as food for humans and $13 \%$ did not know. In the rural area, only $6 \%$ of respondents believe that they can be consumed, $89 \%$ reported that bats are not intended to be consumed and 5\% did not know. The reports of aversion and disgust of people can be seen in the results presented on this question. Only 13\% said they knew about the use of bats as food for human consumption, but were very emphatic in saying that in Brazil this consumption does not exist. According to them, The United States, Cuba and Africa are the common places of occurrence of consumption of bats.

In the urban area, when asked if the bats played important functions for humans and nature, 41 of respondents say no for humans, while for the nature 93 responded that bats do play important environmental services. Among the cited benefits are pollination, seed dispersal, and participation 
in the food chain as insect predators. In addition, bats are used in scientific experiments. In rural areas, $27 \%$ of respondents answered that bats are only important for nature, 38\% said they are useless, and $35 \%$ said bats are useful for humans and for nature. Among the benefits cited are seed dispersal, participation in the food chain and as insect predators. With respect to the importance of bats for humans and nature, $60 \%$ do not realize that benefits provided to the environment, reflect directly in humans. However, the percentage of individuals from rural areas (35\%) who realize the benefits that bats can bring both for humans and for nature was much more relevant than the percentage of urban area dwellers (7\%). This result demonstrates that those areas that contain more vegetation, more food resources and more natural areas, such as rural areas, allow more frequent observations of natural phenomena, such as the seed dispersal and pollination carried by bats.

\section{Discussion}

With regard to the average level of education, significant differences between the responses from residents of urban and rural areas were not observed. However, many concepts and perceptions about bats, emitted by respondents are not consistent with what we found in the scientific literature and/or textbooks. With respect to the top level category in progress or complete, there was a significant difference between urban (48) and rural (6), however, even those individuals who are attending or have attended higher education is not able to give basic information about bats such as, for example, classify them as mammals. This can be attributed to the lack of depth in the teaching of biology at school.

Spiassi and Silva (2008) pointed out that textbooks are extremely important resources as they represent, in many cases, the only available material for students and teachers. However, one has to resort to other sources so there is an expansion of the data so that certain concepts reflect not later on distorted notions not only about the bats, but also other animal victims of prejudices, for example snakes, insects and amphisbaenians.

A considerable percentage (63\%) of respondents did not classify bats as mammals. Out of these, 19\% believe they are insects. In similar work, Drummond (2004) pointed out that $13 \%$ of respondents said that bats are insects, and people used some criteria to classify them as insects: they fly, they come out at night, have no benefit to man; they suck blood, they are deleterious. On the other hand, $12 \%$ of respondents rated bats as rats. The word bat refers to most people the figure of a winged mouse, nocturnal and bloodsucker. This folk perception is reinforced by the morphology of the species of bats of the Family Molossidae, due to the highly visible free tail, like the tail of some rodents. Furthermore, a widespread myth around the country is that the old rats turn into bats, and the difference between urban and rural areas was only $2 \%$.

Regarding the classification of bats and birds ( $11 \%$ of respondents), the main argument used for this categorization was related to the presence of wings and the habit of flying. Most people identified bats as "night birds". The lack of contact with the bats, especially for being nocturnal, prevents further observation of their morphology, the presence of which is the outstanding feature in the group of mammals.

Due to lack of knowledge about the habits of these animals, most of the respondents both in rural and urban areas, a percentage of $23 \%$, attributed pejorative adjectives to the bats, especially with respect to dirt and diseases transmission. These associations may be related to the fact that the majority of respondents believe that bats inhabit only dark and dirty places. Most species of bats live in buildings, caves and hollow trees.

According to Drummond (2004), a widespread myth is that all bats are carriers of rabies. The bats, such as other mammals, are capable of acquiring certain diseases, whether viral, bacterial, through protozoans, fungi, etc. Rabies is a disease caused by the lyssavirus (Rhabdoviridae) that manifests itself only in mammals. Bats 
are therefore capable of acquiring the rabies virus, which is transmitted by saliva or blood of an infected animal through biting, which is defensive, except for the blood sucking species. However, this does not mean that all bats have the rabies virus or are sick and spreading the disease. Only a bat that has been infected may carry the virus. The greatest rabies transmitters are dogs and cats, however, environmental changes caused by human intervention, such as urban sprawl, had an important impact on the occurrence of rabies transmitted by wild animals (Babboni and Modolo, 2011).

The rate of individuals who kill or try to kill the animal (20\%) reflects a common practice among the population, which considers the bats and other animals as harmful to human society. Also, when you do not kill, panic reactions and fear have been reported both in urban as in rural areas, however there is greater concern in the animal conservation in the urban area, as only $13 \%$ have said they kill the animal, while in the countryside $28 \%$ sacrifice the animal whenever they find it.

The fact that frugivory has been the most cited diet, both in urban and rural areas, should be due to the fact that people observe these mammals consuming fruits, and do not detect the hunting insects, or animals ingesting blood or looking for other food items. In the districts of the Municipality of Feira de Santana there are several species of plants whose fruits are eaten by bats, like almond, mango and banana trees. In the rural area there is the greatest record variety of plant species used by these mammals. Citing the frugivory, people always refer to the seeds and fruits of debris observed on the floor of their houses, on balconies and next to plants that serve as shelters for bats. However, much of the sampled population is unaware of the environmental service performed by bats in seed dispersal when the animal performs the seed rain, or in relation to the plant species pollination. Neuweiler (2000) ensures that 64 families of plants, comprising a total of 270 genera and 750 species, are dependent on nectarivores and fruit-eating bats for their reproduction and dispersion; of this total, 590 species of plants are to be found in Neotropical countries, such as Brazil.

Although it was cited in third place as the diet more practiced by bats, the insectivory is prevalent in many families, about 70\% (Kunz et al., 2011). Despite the term, the insectivory includes, besides the insects, arthropods and arachnids, crustaceans, millipedes and other small invertebrates. To consume them, bats active in population control of these animals and take part in the food chain, many of which are agricultural pests and vectors of disease to humans (Sá-Neto, 2000; Altringham, 1996).

Consumption of blood was cited second both in urban and rural areas. In urban area, possibly the belief that all bats feed on blood and the information of frequent attacks of vampire bats in breeding, in the countryside, favor the prejudice that all bats are blood sucking. In both, the Maria Quitéria District and in Humble, several people have reported certain frequency of wounds and bites in animals, characteristic of the vampire bats attack. One respondent mentioned that amazes bats that feed on the blood of their cattle with plant twigs known in the region as nettle (Urtica dioica), placing them in the enclosure where cattle is confined at night, which because of the stinging structures present on the leaves, the bats cannot pass.

Among the feeding habits, necrophagy does not match the reports found in the scientific literature; however, this food behavior was cited by a respondent living in the urban area, when he said that bats ate garbage and dead animals. It is assumed that the subject believe that bats are rats and associate this diet to the presence of these animals in garbage dumps or feeding on debris and organic matter. In addition to this habit, other three were cited by one respondent, which do not appear in any literature, such as fungi intake, roots and sap of plants.

The myth most cited among respondents $(17 \%)$ is that bats suck the blood of animals and humans, when in fact they lick. These animals possess a 
specialized tongue, to take an average of $20 \mathrm{~mL}$ each evening meal (Fenton, 1992). Furthermore, it was also mentioned that bats suck the blood to kill the animal, which is not true. The only reasons that can lead to the death of a pet attacked by vampire bats are transmitting a lethal virus, like rabies; if the wound caused by the bite is infected; if the animal acquires profound anemia after several constant attacks, or screwworm and invasion of other parasites.

The second most cited (16\%) was the vampire. This is due mainly to the strong association with eating habits combined with the media sources that reinforce the vampire figure relating it to the bats, both in film and on television. It was believed that the vampire bats had an anesthetic effect substance in the saliva (Drummond, 2004), which caused the bite during feeding attack to be painless or at least barely noticeable. Although bat's saliva is not anesthetic, its anticoagulant has been proven and used in medicine. This comment was also made in this study, when asked about the use of bats or products from them in the traditional or conventional medicine, one of the interviewees mentioned that there is an anesthetic substance in the saliva of bats that could be used in conventional medicine for manufacturing medications.

One reason that can lead to the interpretation that all bats are identical and present a dark color, usually black, and often are not seen to their morphological characteristics are noted. However, there are several types of color besides black, including white, as bats the genus Diclidurus, and several morphological characteristics that differentiate the species such as the presence or absence of uropatagium, free tail, papillae on the lips, dentition, among others. Drummond (2004) quoted from the questionnaires applied to the population of Vitoria da Conquista BA, that $82 \%$ of respondents reported the black color as the most representative for the bats. Among the other respondents, $43 \%$ are aware of only one type of bats and another $5 \%$ said there were three or four different species.
Drummond (2004), by applying questionnaires in his research, found that $22 \%$ of respondents believed that bats are blind, and 39\% considered that these animals do not see well. Among those who felt the bats like blind men, a portion of these respondents reinforced his statement justifying that instead of vision, bats have another resource when they fly in darkness, citing the sonar. Nevertheless, in this study, only $1 \%$ of respondents cited this myth. The idea of aversion to light is also quite common, and although in fact the bats prefer to be in less enlightened environments, there is an exaggerated inclination to think that luminosity affects them. Not all species of bats inhabit only very dark environments during the day. Many species from Asia and Africa spend their days hanging on the branches of large trees of sparse foliage, being directly affected by sunlight, on tree trunks exposed to daylight. The story of this myth deserves mention because it was made by a respondent with higher education and training in the field of Biological Sciences.

Ethnozoological studies conducted in Brazil often reveal a negative connotation in relation to the bats; however, in other countries, such as China, bats are often seen as synonymous with good luck (Bredt et al., 1996). The lack of knowledge and lack of interest is the main reason for many negative reactions that much of the world's population presents with regard to bats. Most of these reactions are because of these animals behavior of ignorance, especially when it comes to feeding habits, because most people believe that consumption of blood is the prevalent diet within bats.

For lack of knowledge, many colonies are wiped out by the use of insecticides and other agents, generally with insectivorous species that inhabit the lining of houses, schools and churches. In the countryside, many colonies of vampire bats do not end up being decimated as they are subjected to the action of lethal chemicals, which act on population control of vampire bats, which are applied indiscriminately, killing other species. 
There are no surveillance competent bodies, and bats do not appear to be seen as wildlife, as are birds and primates, for example. As part of the native fauna, all bat species are also protected by the same laws as other native animals. However, few are punished for killing bat colonies.

Education is the most appropriate tool to lessen prejudice against bats. The work should start with early childhood education, with basic information provided by parents and/or guardians, and school. In basic education, they suggest projects that address the importance of the species to the maintenance of ecosystems, improving the content of the textbooks, since many bring superficial information that only confirm the prejudice against bats and other animals considered undesirable, such as snakes, spiders, scorpions. Higher education, particularly the areas of biology and agronomy, should reinforce the importance of bats and care needed for environmental monitoring and health surveillance in the colonies.

For the general population, who did not complete basic education, the suggestion is to provide information through leaflets, brochures, presentations in communities and to promote more courses for health workers who are in direct contact with the population and that can be multipliers of valuable information that would help in the conservation and management of these animals.

\section{Acknowledgements}

The Graduate Program in Zoology (PPGZoo) of the State University of Feira de Santana. Dr. Francisco José Bezerra Souto (UEFS) and Dr. Rubén Barquez (PIDBA) for their valuable contributions in this manuscript. To Binael Soares-Santos and Sávio Drummond, in memoriam.

\section{Conflict of interest statement}

Authors declare that they have no conflict of interests.

\section{References}

Andrigueto, A. C.; Cunha L. Role of education in the deconstruction of myths and beliefs about bats. Rev. Elect. Mestrado Educ. Amb., v. 12, p. 123-134, 2004.

Allen, G. M. Bats. New York: Dover Publications, 1967.

Alves, G. M. Morcegos na Fazenda Lageado: concepções dos moradores e riqueza de espécies em uma trilha ecológica. Botucatu: Universidade Estadual Paulista, 1999. (Monograph thesis).

Altringham, J. D. Bats: biology and behavior. New York: Oxford University Press, 1996.

Babboni, S. D.; Modolo, J. R. Raiva: origem, importância e aspectos históricos. UNOPAR Cient. Ciênc. Biol. Saúde, v. 13, esp., p. 34956, 2011.

Bredt, A.; Araújo, F. A. A.; Caetano-Júnior, J.; Rodrigues, M. G. R.; Yoshizawa, M.; Silva, M. M. S.; Harmani, N. M. S.; Massunaga, P. N. T.; Bürer, S. P.; Porto, V. A. R.; Uieda, W. Morcegos em áreas urbanas e rurais: manual de manejo e controle. Brasília: Fundação Nacional de Saúde, 1996

Bruno, M.; Kraemer, B. M. Percepções de estudantes da $6^{\text {a }}$ série $\left(7^{\circ}\right.$ ano) do "Ensino Fundamental” em uma escola pública de Belo Horizonte, MG sobre os morcegos: uma abordagem etnozoológica. e-Scientia, v. 3, No. 2, p. 42-50, 2010. Available from: $<$ http://revistas.unibh.br/index.php/dcbas/article /view/169/99>. Accessed on: Dec. 23, 2016.

Drummond, S. M. Morcegos: verdades e mitos. Uma análise acerca do conhecimento sobre os morcegos na sociedade: folclore, realidade e cultura. Vitória da Conquista: Universidade Estadual do Sudoeste da Bahia, 2004. (Monograph Thesis).

Fenton, M. B. Bats. New York: Facts on File, 1992.

Knight, A. J. "Bats, snakes and spiders, Oh my!": How aesthetic and negativistic attitudes, and other concepts predict support for species protection. J. Environ. Psychol., v. 28, p. 94-103, 2008. https://doi.org/10.1016/j.jenvp. 2007.10.001

Kunz, T. M.; Torrez, E. B.; Bauer, D.; Lobova, T.; Fleming, T. H. Ecosystem services provided by bats. Ann. NY Acad. Sci., v. 1223, No. 1, 
p. 1-38, 2011. https://dx.doi.org/10.1111/j.17496632.2011.06004.x

Mendes, F. R.; Mikich, S. B.; Bianconi, G. V.; Pedro, W. A. Mammals of the City of Phoenix, Paraná, Brazil: ethnozoology and conservation. J. Zool., v. 22, No. 4, p. 991-1002, 2005.

Neuweiler, G. The biology of bats. New York: Oxford University Press, 2000.

Nogueira, M. R.; Lima, I. P.; Moratelli, R.; Tavares, V. C.; Gregorin, R.; Peracchi, A. L. Checklist of Brazilian bats, with comments on original records. Check List, v. 10, p. 808-821, 2014. http://dx.doi.org/10.15560/10.4.808

Prokop, P.; Tunnicliffe, S. D. "Disgusting” animals: primary school children's attitudes and myths of bats and spiders. Eurasia J. Math., Sci. \& Tech. Ed., v. 4, p. 87-97, 2008. Available from: <http://www.ejmste.com/Disgusting-Animals-Primary-School-nChildrens-Attitudes-and-Myths-of-nBats-andSpiders,75309,0,2.html>. Accessed on: Dec. 23, 2016.

Sá-Neto, R. J. Morcegos em área urbana: aspectos reprodutivos e alimentares de Phyllostomus discolor (Chiroptera: Phyllostomidae) em Salvador, Bahia. Salvador: Universidade Federal da Bahia, 2000. (Monograph Thesis).

Spiassi, A.; Silva, E. M. Análise de livros didáticos de Ciências: um estudo de caso. Trama, v. 4, No. 7, p. 45-54, 2008. Available from: <http://e-revista.unioeste.br/index.php/ trama/article/view/2413>. Accessed on: Dec. 23, 2016.

License information: This is an open-access article distributed under the terms of the Creative Commons Attribution License, which permits unrestricted use, distribution, and reproduction in any medium, provided the original work is properly cited. 